\title{
Secretome of adipose derived stem cells induced apoptosis in anaplastic thyroid carcinoma C-643 cells
}

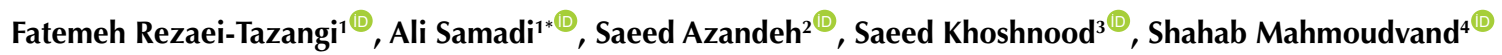 \\ 'Department of Basic Sciences, School of Medicine, Bam University of Medical Sciences, Bam, Iran \\ ${ }^{2}$ Cellular \& Molecular Research Center, Medical Basic Sciences Research Institute, Ahvaz Jundishapur University of Medical Sciences, \\ Ahvaz, Iran \\ ${ }^{3}$ Clinical Microbiology Research Center, Ilam University of Medical Scienes, Ilam, Iran \\ ${ }^{4}$ Department of Virology, School of Medicine, Ahvaz Jundishapur University of Medical Sciences, Ahvaz, Iran
}

\section{*Correspondence to}

Ali Samadi, Ph.D., Email;

alisamadi23@mubam.ac.ir

Received 28 July 2021 Accepted 3 Sep. 2021 Published online 26 Sep. 2021

Keywords: Mesenchymal stem cells, Secretome, Thyroid carcinoma, Viability, Apoptosis

\section{Abstract}

Introduction: Previous studies have proven that secretory materials of mesenchymal stem cells (MSCs) (secretome) have remedial properties.

Objectives: The main goal of this study was to evaluate the effects of secretome of adipose-derived MSCs on growth and apoptosis in anaplastic thyroid carcinoma (ATC) C-643 cells.

Materials and Methods: Initially, thyroid carcinoma cells were exposed to the 25 and $50 \mu \mathrm{g} / \mathrm{mL}$ adipose-derived stem cells (ADSCs) secretome for 24 and 48 hours, to evaluate the proliferation and cytotoxicity of the C-643 cells, MTT [3-(4,5-dimethylthiazol-2-yl)-2,5-diphenyltetrazolium bromide] test and colony assay was conducted. Acridine orange/ethidium bromide (AO/EB) staining was conducted to evaluate the apoptosis. The expression level of apoptosis-associated genes was determined by real-time polymerase chain reaction (PCR) technique. Results: Cell viability and colony numbers in groups exposed to secretome were significantly lower than the control group. The amount of apoptosis-related genes (Bax/Bcl-2, P53, caspase-3 and caspase-8) expression in secretome-treated groups was more than the control group.

Conclusion: The data revealed that ADSCs secretome caused the significant reduction of cell growth and induced apoptosis in C-643 cells.
Citation: RezaeiTazangi F, Samadi A, Azandeh S, Khoshnood S, Mahmoudvand S. Secretome of adipose derived stem cells induced apoptosis in anaplastic thyroid carcinoma C-643 cells. Immunopathol Persa. 2022;8(1):e20. DOI:10.34172 ipp.2022.20.

\section{Introduction}

Thyroid tumors constitute $1 \%$ of all neoplasms. $5 \%$ to $15 \%$ of malignant thyroid tumors include anaplastic thyroid carcinoma (ATC) (1,2).

ATC is one of the thyroid malignancies that is very aggressive, has a high mortality and is a threat to human health. Unfortunately, the probability of living more than five years after contracting this disease is less than 5\% and most patients die in the early months after being diagnosed. ATC is more common in older people (with an average age of about 60) and is more common in women than in men $(3,4)$.

The probability of successful surgery depends on many factors such as the age of the person, the presence of the underlying disease and the rate of progression of the disease at the time of diagnosis.

Chemotherapy and radiotherapy procedures can also damage normal cells $(5,6)$. Thus, it is necessary to discover a new treatment method, which is not harmful to normal cells.

Mesenchymal stem cells (MSCs) have

\section{Key point}

Previous studies show that secreted factors (secretome) of mesenchymal stem cells have therapeutic effects. Numerous studies have investigated the mesenchymal stem cells effects on different cancer types. This study has demonstrated the toxic effect of adipose-derived stem cells secretome against thyroid cancer cells in vitro.

several sources, such as bone marrow, adipose tissue and umbilical cord. They are multipotent cells that have self-renewal and expansion potential. Additionally, they secrete many paracrine factors, which have anti-inflammatory and anti-cancer properties and are called the secretome (7-9).

Due to the secretion of paracrine substances, MSCs have a great effect on the treatment of diseases, including various cancers.

MSCs play a dual role in modulation of cancer cells and can either inhibit or support the growth of tumor cells. Previous studies have shown that MSCs can affect a variety

\footnotetext{
Copyright $(\odot 2022$ The Author(s); Published by Nickan Research Institute. This is an open-access article distributed under the terms of the Creative Commons Attribution License (http://creativecommons.org/licenses/by/4.0), which permits unrestricted use, distribution, and reproduction in any medium, provided the original work is properly cited.
} 
of cancers. However, the results of these studies are contradictory and the precise mechanism of this effect has not yet been determined (12-15).

The results of these studies depend on numerous factors such as origin and type of tumor, type of study and animal species (16). Identifying the effect of the scrotum on the signaling pathways leading to cancer cell death can help treat various cancers.

Among the MSC sources, adipose tissue is more abundant and accessible $(17,18)$. Adipose-derived mesenchymal stem cells (ADMSCs) possess to release ability of cytokines, hormones and growth factors. In this study, the effects of ADSCs secretome on an ATC cell line (C-643) were evaluated.

\section{Objectives}

Given the many benefits of MSCs, this study aims to discover a new method for treating thyroid cancer that could be used to make anticancer drugs.

\section{Materials and Methods}

\section{ADSCs isolation and characterization}

Human subcutaneous adipose tissue was achieved through liposuction surgery and transferred to the cell culture laboratory under sterile conditions. After washing with phosphate-buffered saline (PBS), the fat pieces were exposed to type I collagenase $(1.0 \mathrm{mg} / \mathrm{mL}$ in DMEM) for 30 minutes at $37^{\circ} \mathrm{C}$. Then, the obtained homogenous cell suspension was centrifuged at $1200 \mathrm{rpm}$ for 10 minutes. The obtained cell pellet was re-suspended in DMEM and then cultured in $25 \mathrm{~cm}^{2}$ flasks. The culture medium was exchanged every three days and when the confluency gained about $80 \%$, the cells were passaged. After $3^{\text {rd }}$ passage, cell characterization was conducted using flow cytometry to determine specific markers. Alizarin-red and oil red $\mathrm{O}$ staining was used to evaluation of osteogenic and adipogenic differentiation (Figure 1).

\section{Culture of C-643 cells}

ATC cell line (C-643) was purchased from National Center for Genetic Resources of Iran. C-643 cells were grown in RPMI 1640 medium supplemented with $1 \%$ penicillin-streptomycin, $2 \mathrm{mM}$ L-glutamine and $10 \%$ fetal bovine serum and were incubated in the presence of moist temperature with $5 \% \mathrm{CO}_{2}$ at $37^{\circ} \mathrm{C}$ (Figure 2).

\section{Preparation of secretome}

The ADSCs (after $3^{\text {rd }}$ passage) were cultured in media supplemented $10 \%$ FBS until $80 \%$ confluence. The cells were washed with PBS, and incubated with serumfree media for 20 hours. The conditioned medium was collected and centrifuged for 10 minutes $\left(4^{\circ} \mathrm{C}, 4000 \mathrm{~g}\right)$. Then, $10 \mathrm{~mL}$ conditioned medium re-centrifuged (4000 g) with Amicon Ultra-15 centrifugal filter devices with 3000 molecular weight cut off membrane (Millipore, USA) at $4^{\circ} \mathrm{C}$ for 2 hours. The BCA kit (Thermo Scientific, USA) was

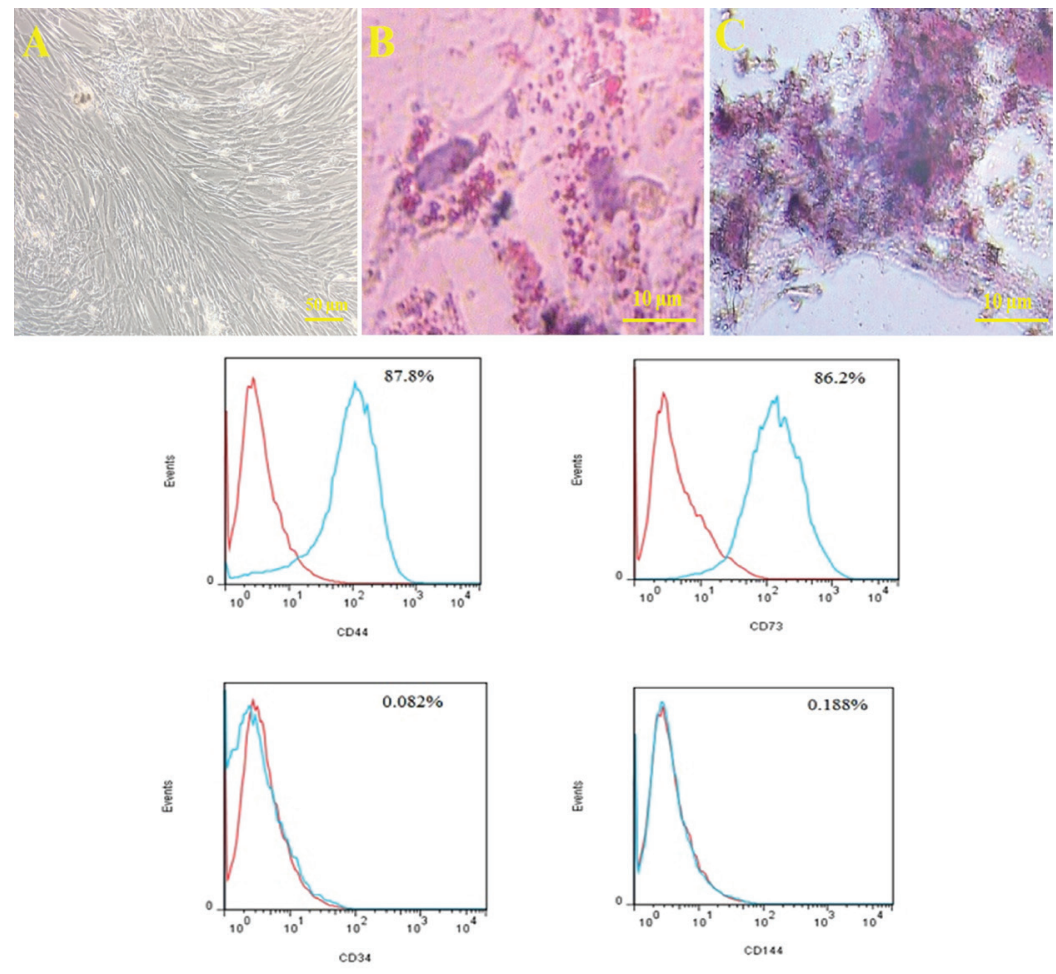

Figure 1. ADSCs at passage 3 show spindle morphology (A). Adipogenic (B) and osteogenic (C) differentiation potential of ADSCs. Oil Red O staining (B) and Alizarin Red staining $(C)$ are positive, indicating the osteogenic and adipogenic differentiation potential of ADSCs. Characterization of ADSCs by flow cytometry (lower panel). ADSCs show high expression of mesenchymal stem cell surface markers (CD44 and CD73), and low expression of hematopoietic stem cell surface markers (CD34 and CD144). 

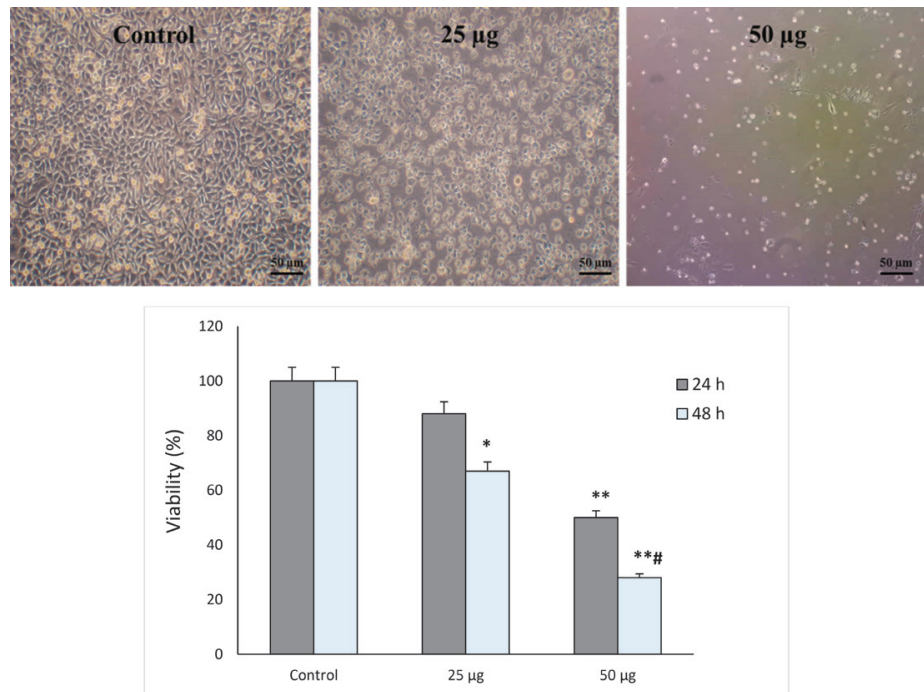

Figure 2. The morphology of C-643 cells in control and $24 \mathrm{~h}$ incubation with $25 \mu \mathrm{g} / \mathrm{mL}$ or $50 \mu \mathrm{g} / \mathrm{mL}$ ADSCs-Secretome (Se) (upper panel). Viability percentage of C-643 cells at different concentrations and incubation times are indicated in lower panel. Each assay has been done six times (3 replicates per each assay), and the mean \pm standard deviations have been indicated. ${ }^{*} P<0.05, * * P<0.01, \# P<0.05 ; *$ and $\#$ symbols indicate comparison to the control and $25 \mu \mathrm{g} / \mathrm{mL}$ ADSCs-Se groups, respectively.

utilized to assess the protein content of the supernatants in accordance with the manufacturer's protocol, stored at $-80^{\circ} \mathrm{C}$ until use.

\section{Cell viability assay}

Cell viability was assessed by MTT assay for evaluation of cytotoxic effect of ADMSCs secretome on C-643 cells. Briefly, culturing C-643 $\left(1 \times 10^{4}\right.$ cells/well $)$ cells was conducted in 96-well plates. After 24 hours, the culture medium was replaced with various concentrations $(25 \mu \mathrm{g}$ and $50 \mu \mathrm{g}$ ) of secretome for 24 and 48 hours. When the cells were treated, MTT solution with $0.5 \mathrm{mg} / \mathrm{mL}$ concentration was added to wells, then the plate was incubated at $37^{\circ} \mathrm{C}$ for 4 hours. Then the supernatant was drained and 100 $\mu \mathrm{L}$ of DMSO was added to all of the wells. Finally, the absorbance was measured at $570 \mathrm{~nm}$ by a microplate reader (Bio-Rad, CA, USA). IC50 values were determined using MTT assay. Each trial was conducted by triplicate.

\section{Colony assay}

C-643 cells were seeded on 6-well plates at a density of 500 cells per well. The cells received complete media supplemented with $25-\mu \mathrm{g}$ and $50-\mu \mathrm{g}$ secretome. After 14 days, the cells were stained with $0.1 \%$ crystal violet colored solution for 15 minutes. Finally, the plates were washed and air-dried and a colony count was conducted.

\section{Acridine Orange/Ethidium Bromide (AO/EB) apoptosis assay}

$\mathrm{AO} / \mathrm{EB}$ staining was utilized to distinguish apoptotic cells. Briefly, C-643 cells were cultured in 96-well plate $\left(4 \times 10^{5}\right.$ cells/well $)$ and incubated for 24 hours. The cells were treated with $25 \mu \mathrm{g}$ and $50-\mu \mathrm{g}$ secretome for 24 hours. Following cells washing with PBS, $20 \mu \mathrm{L}$ of cell suspension was mixed with $1 \mu \mathrm{L}$ of $\mathrm{AO}-\mathrm{EB}$ working solution $(1 \mu \mathrm{L}$ of $\mathrm{AO}$ and EB stocks plus $1 \mathrm{~mL}$ PBS) and the cells were looked under fluorescence microscope immediately. The green and orange cells represented living and dead cells, respectively.

\section{Real-time polymerase chain reaction (RT-PCR)}

Total RNA extraction was conducted using the RNeasy Mini kit (QIAGEN) In accordance with the manufacturer's instructions. RNA concentration and purity were measured using Nanodrop spectrophotometer. cDNA was synthesized using a cDNA Synthesis kit from $6 \mu \mathrm{g}$ of total RNA regarding the manufacturer's instruction. About $2 \mu \mathrm{L}$ of cDNA was augmented in each $25 \mu \mathrm{L}$ PCR reaction compound with $12.5 \mu \mathrm{L}$ of $2 \mathrm{x}$ SYBR Green Master Mix (Fermentas, Canada), 10.1 $\mu \mathrm{L}$ DEPC water, reverse primers, and $0.2 \mu \mathrm{L}$ of each $10 \mathrm{pM}$ forward. Table 1 reports sequences for each primer. PCR was amplified in 40 cycles via the program below: $95^{\circ} \mathrm{C}$ for $10 \mathrm{~min}$, $95^{\circ} \mathrm{C}$ for 15 seconds, and $95^{\circ} \mathrm{C}$ for 30 seconds, and also $60^{\circ} \mathrm{C}$ for 34 seconds. Data analysis was conducted by the $2^{-\triangle \Delta \mathrm{CT}}$ method. Expression values were corrected for the housekeeping gene GAPDH

\section{Statistical analysis}

Data has been analyzed by SPSS 21.0 (Chicago, IL, USA) through ANOVA. Then, post hoc pair-wise comparison was conducted by Bonferroni technique. $P$ value $<0.05$ was regarded as statistically significant. Each trial was conducted in quadruplicate.

\section{Results}

Cell viability

After 24 hours incubation, no significant difference was seen in the viability percentage of $25 \mu \mathrm{g} / \mathrm{mL}$ treated cells compared with control group. The viability percentage 
of $50 \mu \mathrm{g} / \mathrm{mL}$ treated cells after 24 hours incubation was remarkably diminished compared with the control group $(P<0.01)$. After 48 hours incubation, the viability percentage of cells was considerably diminished from $100 \%$ in control to 48 and $29 \%$ in $25 \mu \mathrm{g} / \mathrm{mL}$ and $50 \mu \mathrm{g} / \mathrm{mL}$ treated cells. Additionally, in $50 \mu \mathrm{g} / \mathrm{mL}$ treated cells, the survival rate of cells was remarkably more than $25 \mu \mathrm{g} / \mathrm{mL}$ $(P<0.05)$ (Figure 2).

\section{Colony assay}

In $25 \mu \mathrm{g} / \mathrm{mL}$ treated cells, the colony numbers were remarkably lower than control group $(P<0.01)$. The colony formation in $50 \mu \mathrm{g} / \mathrm{mL}$ treated cells was remarkably diminished compared with control group $(P<0.001)$ and $25 \mu \mathrm{g} / \mathrm{mL}$ treated cells $(P<0.05$; Figure 3$)$.

\section{AO/EB apoptosis assay}

$\mathrm{AO} / \mathrm{EB}$ double staining protocol is a quick and reliable fluorescence technique to differentiate the viable, apoptotic and necrotic cells. The nuclei of living cells appear bright green. The nucleus of apoptotic cells emits an orange color. Red nuclei indicate necrotic cells (19).

Around $94 \%$ of cells in the control group were viable, $4 \%$ were in apoptosis and $2 \%$ were in necrosis stage. The percentage of viable cells was diminished to $66 \%$ in $25 \mu \mathrm{g} /$ $\mathrm{mL}$ and $40 \%$ in $50 \mu \mathrm{g} / \mathrm{mL}$ secretome (se)-treated cells. In $25 \mu \mathrm{g} / \mathrm{mL}$ se-treated cells, the apoptosis percentage was significantly more than the control group (6.25-fold, $P<$ $0.01)$. The apoptosis percentage of $50 \mu \mathrm{g} / \mathrm{mL}$ se-treated cells was noticeably more than control group (11.75-fold, $P<0.001)$ and $25 \mu \mathrm{g} / \mathrm{mL}$ se-treated cells $(1.88$-fold, $P<$ $0.05)$.

In $25 \mu \mathrm{g} / \mathrm{mL}$ se-treated cells, the necrosis percentage was remarkably more than control group (4-fold, $P<0.05$ ). The necrosis percentage of $50 \mu \mathrm{g} / \mathrm{mL}$ se-treated cells was more than the control group $(6.1$-fold, $P<0.01)$ and $25 \mu \mathrm{g} /$
mL se-treated cells (Figure 4).

\section{Gene expression assessment}

In $25 \mu \mathrm{g} / \mathrm{mL}$ se-treated cells, the expression of Bax gene was significantly more than control group (2.61-fold, $P<$ $0.01)$. The expression of this gene in $50 \mu \mathrm{g} / \mathrm{mL}$ se-treated cells was remarkably more than control group (3.37-fold, $P$ $<0.001)$ and $25 \mu \mathrm{g} / \mathrm{mL}$ se-treated cells (1.4-fold, $P<0.05$ ).

In $50 \mu \mathrm{g} / \mathrm{mL}$ se-treated cells, the expression of Bcl-2 was lower than control group and $25 \mu \mathrm{g} / \mathrm{mL}$ se-treated cells $(P<0.05)$.

The expression of P53 gene in $50 \mu \mathrm{g} / \mathrm{mL}$ se-treated cells was significantly more than control group and $25 \mu \mathrm{g} / \mathrm{mL}$ se-treated cells $(P<0.05$; Figure 5$)$.

In $25 \mu \mathrm{g} / \mathrm{mL}$ se-treated cells, the expression of Caspase- 3 and Caspase- 8 was noticeably more than control group (1.88-fold, $P<0.05)$. In $50 \mu \mathrm{g} / \mathrm{mL}$ se-treated cells, the expression of Caspase-3 was significantly more than control group $(P<0.001)$ and $25 \mu \mathrm{g} / \mathrm{mL}$ se-treated cells $(P<0.01)$. Additionally, the expression of Caspase- 8 in 50 $\mu \mathrm{g} / \mathrm{mL}$ se-treated cells was remarkably more than control group $(P<0.01)$ and $25 \mu \mathrm{g} / \mathrm{mL}$ se-treated cells $(P<0.05)$ (Figure 6).

\section{Discussion}

Previous studies have proven that MSCs have many considerable regenerative attributes, because they can produce a variety of soluble factors that affect tissue structure.

The results of this study showed that exposure of C-643 cells to ADSCs-secretome caused the reduction in viability and cell proliferation while the apoptosis was enhanced. These changes were dose-dependent, so that the maximum was seen in $50 \mu \mathrm{g} / \mathrm{mL}$ se-treated cells. In agreement with this study, Maj et al introduced that conditioned medium of ADMSCs could diminish the viability and proliferation

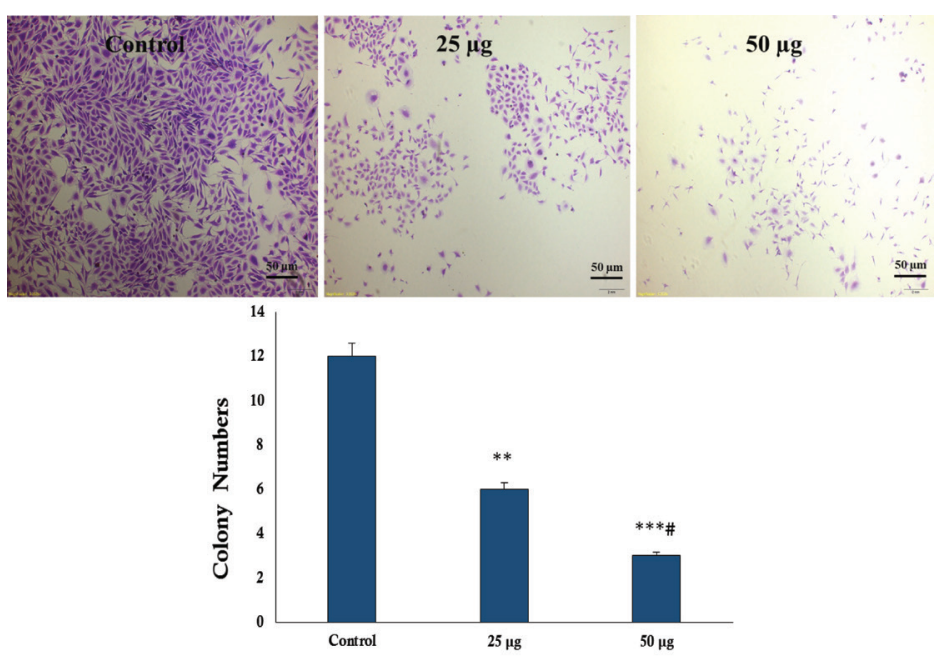

Figure 3. The colony formation of C-643 cells and the number of colonies in different groups. Each assay has been done 6 times ( 3 replicates per each assay), and the mean \pm standard deviations have been indicated. ${ }^{* *} P<0.01, * * * P<0.001, \# P<0.05 ; *$ and \# symbols indicate comparison to the control and $25 \mu \mathrm{g} /$ $\mathrm{mL}$ ADSCs-Se groups, respectively. 


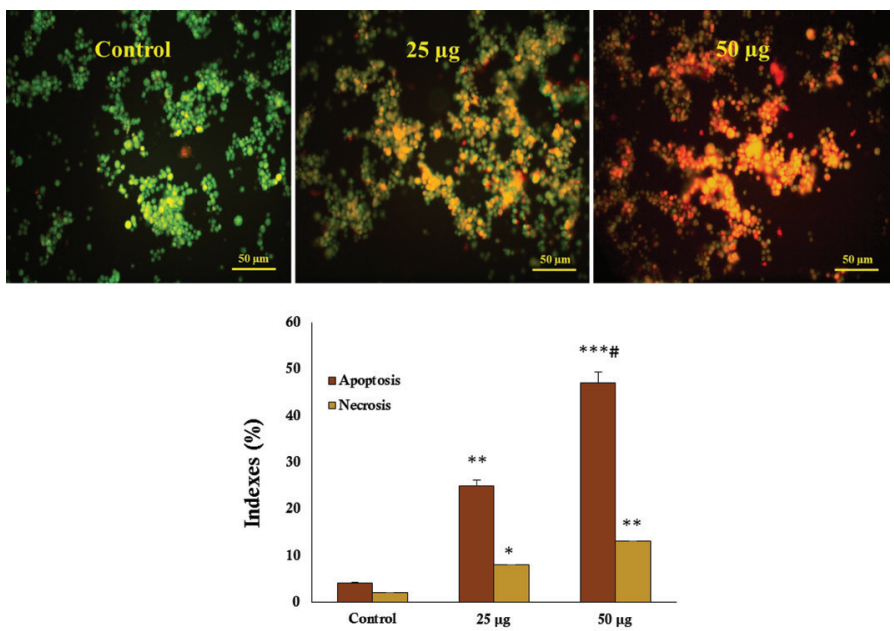

Figure 4. EB/AO staining to distinguish the apoptotic and necrotic cells. The nucleus of normal cells emits fluorescent green light. In early apoptotic cells the nucleus display yellow-green fluorescence. The nucleus of late apoptotic cells display orange fluorescence. Orange-red fluorescence nuclei represent necrotic cells (upper panel). Apoptotic and necrotic indexes have also shown. Each assay has been accomplished 3 times, and the mean \pm SD have been presented. ${ }^{*} P<$ $0.05,{ }^{* *} P<0.01,{ }^{* * *} P<0.001, \# P<0.05 ; *$ and \# symbols indicate comparison to the control and $25 \mu \mathrm{g} / \mathrm{mL}$ ADSCs-Se groups, respectively.

of bladder cancer cells (20). Contrary to this research, Onzi et al, concluded that conditioned medium of ADMSCs had no effect on proliferation of human glioblastoma cancer stem cell but could alter glioblastoma cells migration (21).

In the study by Bielli et al, it was found that in the tumor microenvironment it seems that ADSCs-secretome influence active breast cancer cells and increase neoangiogenesis, matrix remodeling and intercellular communication through Gap Junction, thereby promote cancer metastasis (22).

Apoptosis is one of the most important mechanisms utilized to study the therapeutic effects of anti-cancer drugs. AO/EB assay can easily identify viable, apoptotic and normal cells.

The study of Liu et al showed that dual EB/AO staining is an economic and appropriate method to identify apoptosis in tumor cells compared to flow cytometry. When AO penetrated into normal and early apoptotic cells, it bound to DNA and emitting fluorescent green light. EB interfered to late apoptotic and necrotic cells with damaged membranes bound to DNA fragments or apoptotic bodies and emitting orange-red fluorescence (23).

Exposure of C-643 cells to ADSCs-secretome caused the dose-dependent enhancement of apoptosis and necrosis mechanism.

RT-PCR was another mechanism was utilized to confirm the occurrence of apoptosis in the treated groups. For this purpose, the amount of mRNA expression of Bax, Bcl-2, p53, caspase- 3 and -8 was evaluated.

P53 is a key gene in regulating of cell cycle and tumor suppression. In normal conditions, p53 exits in low levels. However, its expression highly induces under various stresses such as DNA damage and oncogenic activity that leads to form the net of signaling pathways. One of prominent outcomes of p53 activation is apoptosis inducing that can initiate through several pathways. In fact, P53 function as transcriptional factor can activates the expression of a large number of genes including Bax,

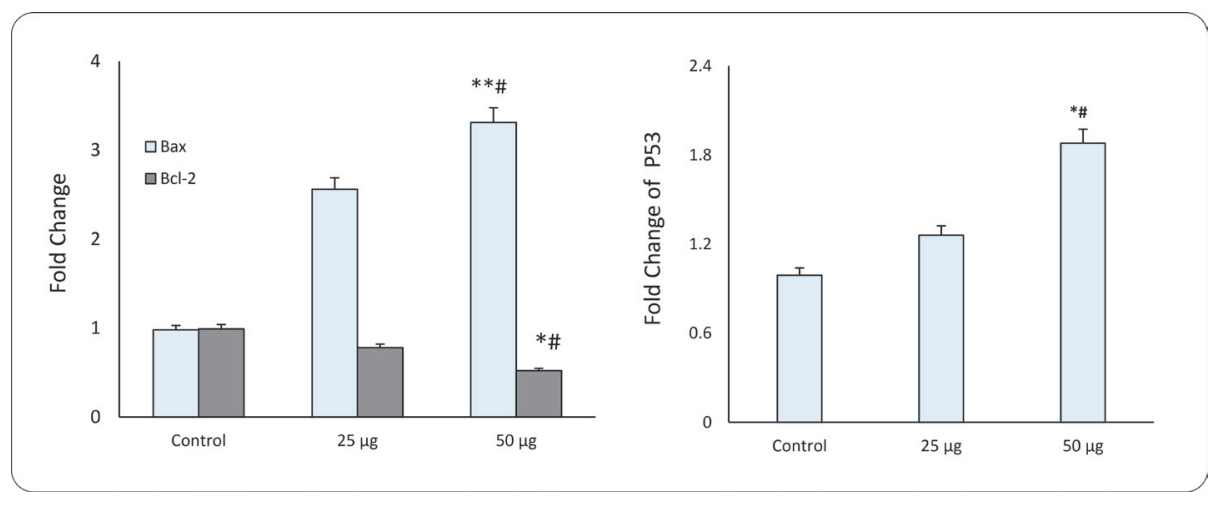

Figure 5. ADSCs-Se effects on gene expression. Expression is shown as fold change relative to control untreated cells. Each assay has been accomplished 5 times, and the mean $\pm \mathrm{SD}$ have been presented. $* P<0.05, * * P<0.01, \# P<0.05 ; *$ and \# symbols indicate comparison to the control and $25 \mu \mathrm{g} / \mathrm{mL} \mathrm{ADSCs}-\mathrm{Se}$ groups, respectively. 


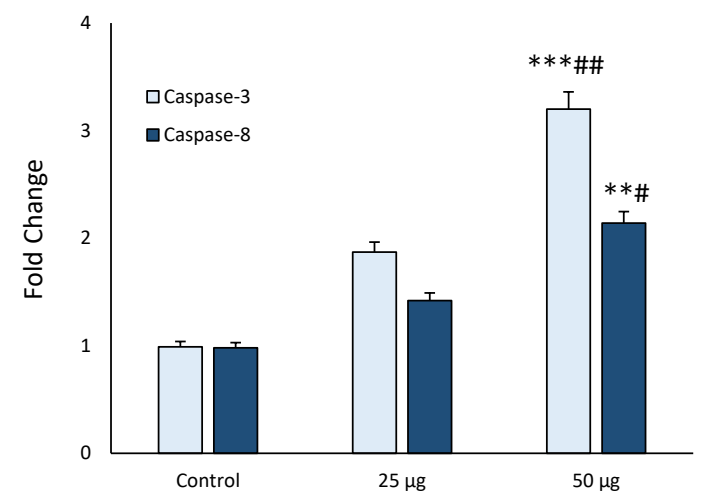

Figure 6. ADSCs-Se effects on Caspases activity. Each assay has been accomplished 4 times, and the mean \pm SD have been presented. $* P<0.05$, $* * P<0.01, P<0.001 ; \# P<0.05 ; *$ and \#symbols indicate comparison to the control and $25 \mu \mathrm{g} / \mathrm{mL}$ ADSCs-Se groups, respectively.

Bak, Puma, Noxa and Bid as well as death receptors which promote apoptosis. On the other hand, the increase of the expression of these genes leads to increase the ratio of pro to anti-apoptotic proteins and consequently, induce extrinsic and intrinsic apoptosis by caspases activation. $\mathrm{Bax}$ and $\mathrm{Bcl}-2$ genes are involved in setting the intrinsic pathway of apoptosis. They are the main members of the Bcl-2 family (24-26).

Exposure to ADSCs-secretome remarkably increases the expression of Bax gene, whereas the Bcl-2 expression was considerably diminished. Chiu et al have demonstrated that condition medium of ADSCs causes the increase of Bax, Caspase- 3 and -9 gene expression, while the expression level of Bcl-2 gene was decreased (27).

The study of Yu et al revealed that condition medium of ADSCs causes the significant increase of Bax protein and reduction of $\mathrm{Bcl}-2$ protein synthesis in bladder tumor cells (28).

In the present study, the expression of Bax, P53, caspase-3 and -8 was significantly increased in ADSCs-secretome treated cells, while Bcl-2 expression was decreased.

Pires et al, demonstrated that cytokines released by bone marrow derived MSCs, such as tissue inhibitor of metalloproteinases-1, and cytokine-induced neutrophil chemoattractant-1 induces differentiation and neurite outgrowth in SH-SY5Y cells (29).

High levels of caspase- 3 and -7gene expression caused the onset of intrinsic apoptosis pathway in the cell (29). The study of Tummers et al revealed that the secretion of TNFa-related apoptosis-inducing ligand by MSCs begins a signaling cascade of caspase-8-dependent apoptosis and activates the extrinsic pathway of apoptosis (31).

\section{Conclusion}

The results of this study revealed that ADSCs-secretome had toxic effects on ATC (C-643) cells in vitro. The findings also indicated that ADSCs-secretome could inhibit the progress of thyroid anaplastic carcinoma through the activation of intrinsic and extrinsic pathways of apoptosis in cancer cells. Confirmation of this claim requires further research in this area both in vitro and in vivo.

\section{Limitations of the study}

Due to financial problems, we were not able to perform more laboratory techniques. Of the different types of thyroid cancer cell lines, we could only study the C-643 cell line.

\section{Authors' contribution}

FRT participated in data collection, analysis and manuscript writing. AS was responsible for supervision and protocol development. SA was included in preparing the concept and design. SKH and SHM assisted in data collection. All authors participated in preparing the final draft of the manuscript, revised the manuscript and critically evaluated the intellectual contents. All authors read and approved the content of the manuscript and confirmed the accuracy or integrity of any part of the work.

Conflicts of interest

The authors declare that they have no competing interests.

\section{Ethical issues}

The Ethics Committee of Bam University of Medical Sciences approved this study (Ethical code \# IR.MUBAM.REC.1400.005). The research also followed the tenets of the Declaration of Helsinki. This study was extracted from a research project was conducted in Bam University of Medical Sciences. Additionally, ethical issues (including plagiarism, data fabrication and double publication) have been completely observed by the authors.

\section{Funding/Support}

This study was supported by Bam University of Medical Sciences, Bam, Iran (Grant\# 99000165).

\section{References}

1. Giuffrida D, Gharib H. Anaplastic thyroid carcinoma: current diagnosis and treatment. Ann Oncol. 2000;11:1083-9. doi: 10.1023/a:1008322002520.

2. Are C, Shaha AR. Anaplastic thyroid carcinoma: biology, pathogenesis, prognostic factors, and treatment approaches. Ann Surg Oncol. 2006;13:453-64. doi: 10.1245/ ASO.2006.05.042.

3. Kebebew E, Greenspan FS, Clark OH, Woeber KA, McMillan A. Anaplastic thyroid carcinoma. Treatment outcome and prognostic factors. Cancer. 2005;103:1330-5. doi: 10.1002/ cncr.20936.

4. Carcangiu ML, Steeper T, Zampi G, Rosai J. Anaplastic thyroid carcinoma. A study of 70 cases. Am J Clin Pathol. 1985;83:13558. doi: 10.1093/ajcp/83.2.135.

5. Smallridge RC, Copland JA. Anaplastic thyroid carcinoma: pathogenesis and emerging therapies. Clin Oncol (R Coll Radiol). 2010;22:486-97. doi: 10.1016/j.clon.2010.03.013.

6. Ain KB. Anaplastic thyroid carcinoma: behavior, biology, and therapeutic approaches. Thyroid. 1998;8:715-26. doi: 10.1089/thy.1998.8.715.

7. González-González A, García-Sánchez D, Dotta M, Rodríguez-Rey JC, Pérez-Campo FM. Mesenchymal stem cells secretome: The cornerstone of cell-free regenerative medicine. World journal of stem cells. 2020;12:1529. doi: 10.4252/wjsc. v12.i12.1529

8. Pittenger MF, Mackay AM, Beck SC, Jaiswal RK, Douglas R, Mosca JD, Moorman MA, Simonetti DW, Craig S, Marshak DR. Multilineage potential of adult human mesenchymal 
stem cells. Science. 1999:284:143-7. doi: 10.1126/ science.284.5411.143.

9. Alhadlaq A, Mao JJ. Mesenchymal stem cells: isolation and therapeutics. Stem Cells Dev. 2004;13:436-48. doi: 10.1089/ scd.2004.13.436.

10. Purnamawati P, Pawitan JA, Rachman A, Wanandi SI. Effects of umbilical cord-and adipose-derived stem cell secretomes on ALDH1A3 expression and autocrine TGF- $\beta 1$ signaling in human breast cancer stem cells. F1000Research. 2018;7:1-13. doi: 10.126888/13609.

11. Yang $H$, Yang $H$, Xie Z, Wei L, Bi J. Systemic transplantation of human umbilical cord derived mesenchymal stem cellseducated T regulatory cells improved the impaired cognition in AßPPswe/PS1dE9 transgenic mice. PLoS One. 2013;8:e69129. doi: 10.1371/journal.pone.0069129.

12. Paiboon N, Kamprom W, Manochantr S, Tantrawatpan C, Tantikanlayaporn D, Roytrakul S, Kheolamai P. Gestational tissue-derived human mesenchymal stem cells use distinct combinations of bioactive molecules to suppress the proliferation of human hepatoblastoma and colorectal cancer cells. Stem Cells Int. 2019;2019:9748795. doi: 10.1155/2019/9748795.

13. Bodart-Santos V, de Carvalho LRP, de Godoy MA, Batista AF, Saraiva LM, Lima LG, et al. Extracellular vesicles derived from human Wharton's jelly mesenchymal stem cells protect hippocampal neurons from oxidative stress and synapse damage induced by amyloid- $\beta$ oligomers. Stem Cell Res Ther. 2019;10:332. doi: 10.1186/s13287-019-1432-5.

14. Format Yagi $\mathrm{H}$, Kitagawa $\mathrm{Y}$. The role of mesenchymal stem cells in cancer development. Front Genet. 2013;4:261. doi: 10.3389/fgene.2013.00261

15. Tran C, Damaser MS. Stem cells as drug delivery methods: application of stem cell secretome for regeneration. Adv Drug Deliv Rev. 2015; 82-83:1-11. doi: 10.1016/j.addr.2014.10.007.

16. Torsvik A, Bjerkvig R. Mesenchymal stem cell signaling in cancer progression. Cancer Treat Rev. 2013;39:180-8. doi: 10.1016/j.ctrv.2012.03.005

17. Nae S, Bordeianu I, Stăncioiu AT, Antohi N. Human adiposederived stem cells: definition, isolation, tissue-engineering applications. Rom J Morphol Embryol. 2013;54:919-24.

18. Dai R, Wang Z, Samanipour R, Koo Kl, Kim K. AdiposeDerived Stem Cells for Tissue Engineering and Regenerative Medicine Applications. Stem Cells Int. 2016;25:34-46. doi: 10.1155/2016/6737345

19. Ciniglia C, Pinto G, Sansone C, Pollio A. Acridine orange/ Ethidium bromide double staining test: A simple In-vitro assay to detect apoptosis induced by phenolic compounds in plant cells. Allelopathy J. 2010; 26:301-8. doi: 10.125/90649352.
20. Maj M, Kokocha A, Bajek A, Drewa T. The interplay between adipose-derived stem cells and bladder cancer cells. Sci Rep. 2018;8:15118. doi: 10.1038/s41598-018-33397-9.

21. Onzi GR, Ledur PF, Hainzenreder LD, Bertoni AP, Silva AO, Lenz G, Wink MR. Analysis of the safety of mesenchymal stromal cells secretome for glioblastoma treatment. Cytotherapy. 2016; 18:828-37. doi: 10.1016/j.jcyt.2016.03.299.

22. Bielli A, Scioli MG, Gentile P, Agostinelli S, Tarquini C, Cervelli V, Orlandi A. Adult adipose-derived stem cells and breast cancer: a controversial relationship. Springerplus. 2014; 3:345. doi: 10.1186/2193-1801-3-345.

23. Liu K, Liu PC, Liu R, Wu X. Dual AO/EB staining to detect apoptosis in osteosarcoma cells compared with flow cytometry. Med Sci Monit Basic Res. 2015;21:15-20. doi: 10.12659/ MSMBR.893327.

24. Singh R, Letai A, Sarosiek K. Regulation of apoptosis in health and disease: the balancing act of BCL-2 family proteins. Nat Rev Mol Cell Biol. 2019;20:175-193. doi: 10.1038/s41580018-0089-8.

25. Duffy MJ, Synnott NC, McGowan PM, Crown J, O'Connor D, Gallagher WM. p53 as a target for the treatment of cancer. Cancer Treat Rev. 2014;40:1153-60. doi: 10.1016/j. ctrv.2014.10.004

26. Lane DP, Cheok CF, Lain S. p53-based cancer therapy. Cold Spring Harb Perspect Biol. 2010;2:a001222. doi: 10.1101/ cshperspect.a001222.

27. Chiu YJ, Yang JS, Hsu HS, Tsai CH, Ma H. Adipose-derived stem cell conditioned medium attenuates cisplatin-triggered apoptosis in tongue squamous cell carcinoma. Oncol Rep. 2018;39:651-658. doi: 10.3892/or.2017.6126.

28. Yu X, Su B, Ge P, Wang Z, Li S, Huang B, Gong Y, Lin J. Human adipose derived stem cells induced cell apoptosis and $\mathrm{s}$ phase arrest in bladder tumor. Stem Cells Int. 2015;2015:619290. doi: 10.1155/2015/619290

29. Pires AO, Neves-Carvalho A, Sousa N, Salgado AJ. The secretome of bone marrow and Wharton jelly derived mesenchymal stem cells induces differentiation and neurite outgrowth in SH-SY5Y cells. Stem Cells Int. 2014:345-362. doi: 10.1155/2014/438352.

30. Han I, Yun M, Kim EO, Kim B, Jung MH, Kim SH. Retraction Note: Umbilical cord tissue-derived mesenchymal stem cells induce apoptosis in PC-3 prostate cancer cells through activation of JNK and downregulation of PI3K/AKT signaling. Stem Cell Res Ther. 2018;9:354. doi: 10.1186/s13287-0181113-9.

31. Tummers B, Green DR. Caspase-8: regulating life and death Immunol Rev. 2017;277:76-89. doi: 10.1111/imr.12541. 